\title{
Economic Growth: How Inflation and the Exchange Rate Work Through the Stock Market as a Mediating Variable
}

Vietha Devia SS

Ph. D Student in School of Economics, Huazhong University of Science and Technology

Wuhan, P.R. 430074, China

Lecturer in Faculty of Economics and Business, University of Brawijaya

Malang, 65144, Indonesia

E-mail: vietha.devia@hotmail.com

Received: September 24, 2019 Accepted: October 22, 2019 Published: November 9, 2019

doi:10.5296/ber.v9i4.15790

URL: https://doi.org/10.5296/ber.v9i4.15790

\begin{abstract}
This study aims to investigate the impact of inflation and the exchange rate on economic growth through the stock market as a mediating variable. The analysis tool used a path model with monthly data. The research period lasted for 14 years from 2004 to 2017. The data was obtained from the Central Statistics Bureau, Bank Indonesia and Jakarta Stock Exchange. Case studies were conducted in Indonesia and the researcher took the Consumer Goods Index as a variable in the stock market. The results show that inflation and the exchange rates do not significantly affect economic growth through the stock market. Alternatively, the stock market is not an excellent mediating variable between inflation and the exchange rate on economic growth. The size of the stock market and the awareness of domestic investors when accessing the stock market is thought to be the factors that influence how the inflation and exchange rates work.
\end{abstract}

Keywords: Inflation, Exchange rate, Economic growth, Stock market, Consumer Goods Index

\section{Introduction}

Macroeconomic variables have been an important consideration, especially for economists, investors and policymakers. Several important macroeconomic variables have been subject to interesting research previously. The first variable is the inflation rate. Inflation is expressed as the percentage change in the aggregate price level over a period of time, typically a year (Ball, 2011). Ehigiamusoe \& Lean (2019) expressed the inflation rate as macroeconomic instability. 
Therefore inflation is a concern for all countries so then stability can be maintained (Pitia \& Lado, 2015). The impact of inflation, although it differs among countries as to the extent, is a worldwide phenomenon (Kara \& Nelson, 2002).

Second is the exchange rate variable. The exchange rate is the price currency used by the countries' citizens to trade with each other (Mankiw, 2016). Evans (2014) defined the exchange rate as the rate or ratio by which one of these currencies can be exchanged for any other at any given point in time. According to Yang \& Zeng (2014), the exchange rate in many literature books is usually defined as the relative price levels between two countries rather than how much the currency can purchase in real terms. The effect of the exchange rate is according to the exchange rate regime adopted by the country. Besides, the impact of the exchange rate fluctuations is a contagion through different channels, such as the balance of payment, import price, FDI and many more. The changes in the exchange rates can determine how the monetary policy must be arranged (Clarida \& Waldman, 2007).

Third is the primary concern of the macroeconomic variables, namely economic growth. Haller (2012) said that in a limited sense, economic growth is an increase of the national income per capita and it involves the expansion of the GDP, GNP and NI. The economic growth variable is strongly suspected as a factor that is vulnerable to the influence of inflation and exchange rates. According to Hossin (2016), inflation can reduce a country's competitiveness at the level of trade which in turn makes the trade balance deficit and economic growth. Vinayagathasan (2013) found that inflation hurts growth when it exceeds $5.43 \%$ but it has no effect below this level. Concerning the exchange rate, based on the Mundel-Flemming model, if depreciation occurs then it will increase the trade competitiveness, leading to an increase in the value of exports and economic growth. Habib, Mileva \& Stracca (2016) reinforced that a real appreciation (depreciation) reduces (raises) significantly the annual real GDP growth.

In addition to the inflation and exchange rates as determining economic growth, there is an essential variable as part of the component of economic growth, namely investment. Investment plays an important role in economic growth throughout the world. For developed economies, they have shared in the global FDI inflow that grew to $59 \%$ with the United States as the largest recipient of FDI, followed by the United Kingdom and China (UNCTAD, 2017). For Indonesia during the crisis of 1997 - 1998, investment grew far below its potential amount. A few years after the reform order, the government succeeded in implementing policies that made for stable economic growth. This fostered confidence in the investors including foreign investors, and thus this increased the FDI inflow (Ramachandran, 2014).

In 2012, investment contributed 33\% to Indonesia's GDP (Ginting \& Aji, 2015). The greater proportion of investment to GDP seems to influence how inflation and the exchange rate work together when influencing economic growth. Eggoh \& Khan (2014) once said that inflation-growth relationships are sensitive to capital accumulation. Ogrokhina \& Rodriguez (2019) also stated that financial market openness is needed to get the benefits of inflation targeting. Concerning the exchange rate, Gelman et al (2015) proved that the real effective exchange rate of investors is the net foreign holdings of their assets. Combes et al., (2019) 
also showed that financial flow can stimulate economic growth, which is where the real exchange rate and FDI play a role.

From the empirical background, it can be said that one of the factors determining the way that the inflation and exchange rate works on economic growth is the level of investment, especially the accumulation of capital or financial flow. One means of investing in terms of capital is the stock market. Therefore the author wants to try to examine the impact of the inflation and exchange rates by considering the existence of mediating variables in the form of a stock market. The author conducted the research in Indonesia by taking the Consumer Goods Industry index as a case study on the stock market. Testing will be carried out using the path method with a 14-year research period from 2004 to 2017.

In Indonesia, the stock market mainly trades with the Jakarta Stock Exchange (JSX) and Indonesia Composite Stock Price Index (ICI) as the indicators of the performances of the stock markets. The ICI has several indexes, and one of them is the Sectoral Index. The Consumer Goods Index is a part of the Sectoral Index in JSX. Alfred in Fuad (2013) shows that the Consumer Goods index sector contributes to ICI growth by more than $50 \%$.

\section{Literature Review}

\subsection{Understanding Inflation and Exchange Rate}

Samuelson (2004) stated that inflation occurs when the general price level increases. On the other hand, Mankiw (2016) said that inflation is prompted by the growth of money supply. Inflation measurements can be done by calculating the average change in the price increase of goods and services during a specified period (Labonte, 2011). Patel \& Villar (n.d.) expressed the inflation measurement as the concept of a "composite good" whose price is measured by a cost-of-goods index.

Garín, Robert, \& Sims (2018) defined the exchange rate in two. First, the exchange rate in real terms measures how many home goods one foreign good will purchase. Second, the exchange rate in nominal term measures how many units of home currency one unit of foreign currency will purchase. Snowdon \& Vane (2005) express the exchange rate as domestic currency in terms of foreign currency.

Some of the previous researchers concluded that several factors also influence the way that inflation works and the exchange rates, which makes them have an indirect effect on economic growth. Eggoh \& Khan (2014) said that inflation is sensitive to a country's level of financial development, capital accumulation, trade openness and government expenditures. Arestis \& Baltar (2018) prove that a real exchange rate can stimulate investment and reinforce the existing productive sector. Ribeiro, McCombie \& Lima (2019) state that the real exchange rate only affects growth indirectly through its impact on functional income distribution and technological innovation.

\subsection{Indonesia Stock Market and Consumer Goods Index}

The Indonesia Stock Exchange is a combination of the Jakarta Stock Exchange and the Surabaya Stock Exchange. On July $13^{\text {th }}$ 1992, the Jakarta Stock Exchange was privatized and 


\section{Macrothink}

Business and Economic Research

ISSN 2162-4860

2019, Vol. 9, No. 4

became the PT. Jakarta Stock Exchange. Then in 2007, the Surabaya Stock Exchange merged with PT Bursa Efek Jakarta and was renamed the PT. Indonesian Stock Exchange.

Generally, an investor uses the Indonesian Composite Index (ICI) to evaluate Indonesia's stock market performances. In ICI, there are some sectoral indexes. One of them is the Consumer Goods Index. The Consumer Goods Industry has recorded an ever increasing trend (OJK, 2010). Even the most robust supports the ICI. Up until 2017, the consumer goods industry index reached 2861.39 while the ICI reached 6355.65 (OJK, 2017a).

\subsection{Economic Growth}

Economists have expressed economic growth in many ways. Parkin (2012) defined the economic growth rate as the annual percentage change of real GDP. Wilson et al. (n.d.) described economic growth as an increase in production and it is generally measured by the increase in Gross Domestic Product (GDP) or Gross National Product (GNP). Haller (2012) reinforced that positive economic growth is recorded when the annual indicators of macro-indicators are higher than the average rhythms of growth in the population.

\section{Research Method}

In this research, the author used path analysis. The consideration was due to there being more than one dependent variable and the existence of intervening variables before the final variable. Streiner (2005) stated that path analysis is capable of testing a model possessing several dependent variables. There is a "chain" effect in terms of their influence (see Figure 1). The study period started in 2004 to 2017 and used monthly data.

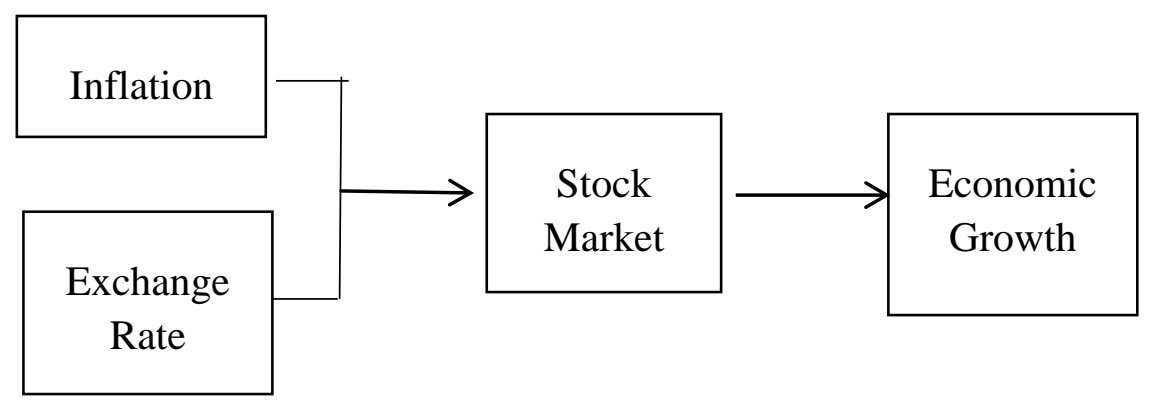

Figure 1. Path Model, the Effect of Inflation and Exchange Rate on Economic Growth through Stock Market

The author used the consumer price index data for the inflation variables. Concerning the exchange rate, author used the real exchange rate of Rupiah against USD. As for the stock market, it used the Consumer Goods Index. For economic growth, the author used the percentage change in real GDP. 


\section{Result and Discussion}

\subsection{Assumption Test}

The author used AMOS software for the data analysis. There were two assumptions for the requirements of the path model. First, the assumption requirement must be fulfilled, namely the normality assumption. Table 1 shows the value of the CR Multivariate Normality of | -2.408 |, which is greater than 1.96 (obtained from the Standard Normal Statistics Table 5\%). It means that the data is abnormally distributed. However, based on the central limit argument, if the sample gets bigger, then the statistics will be normally distributed. With a 168 sample size, the data is deemed to fulfill the central limit argument, meaning that the assumption of normality can be ignored.

Table 1. Result of Normality Test

\begin{tabular}{|l|l|l|l|l|l|l|}
\hline Variable & Min & $\max$ & skew & c.r. & kurtosis & c.r. \\
\hline Exchange Rate & 8455.000 & 14650.000 & .750 & 3.919 & -1.042 & -2.723 \\
\hline Inflation & 104.600 & 164.010 & .542 & 2.836 & -.319 & -.834 \\
\hline Stock Market & 206.360 & 2861.390 & .237 & 1.238 & -1.523 & -3.981 \\
\hline Economic growth & -10.500 & 11.390 & -.316 & -1.650 & 2.006 & 5.243 \\
\hline Multivariate & & & & & -2.605 & -2.408 \\
\hline
\end{tabular}

Source: Output of AMOS

The second assumption is that there are no outliers. The test author used the Mahalanobis distance (Md). The Mahalanobis distance was evaluated using the free degree as much as the number of parameters in the model used, which was $=11$ where the statistical table was 31,264. The rules of decision making are as follows: if the Md observation point> 31.264, then it can be concluded that the observations contained an outlier, whereas if the $\mathrm{Md}$ observation point $<31.264$, then it can be concluded that the observation involves no outliers. The whole Mahalanobis d-squared observation based on Table 2 has a value between 2.685 9.387, which is smaller than 31.264. Therefore, no outlier assumption has been fulfilled.

In addition to seeing the value of Mahalanobis d-squared, whether the no outlier assumption is fulfilled or not, it can also refer to the values of $\mathrm{p}_{1}$ and $\mathrm{p}_{2}$. The number of $\mathrm{p}_{1}$ and $\mathrm{p}_{2}$ indicates the significance value. If the value of $\mathrm{p}_{1}$ and $\mathrm{p}_{2}<0.05$, then there are outliers. Based on Table 2, the values of $\mathrm{p}_{1}$ and $\mathrm{p}_{2}$ have values between $0.052-1,000$, so therefore the assumption of there being no outliers is fulfilled.

Table 2. Result for No Outlier Assumption

\begin{tabular}{|l|l|l|l|}
\hline Observation number & Mahalanobis d-squared & $\mathrm{p} 1$ & $\mathrm{p} 2$ \\
\hline 67 & 9.387 & .052 & 1.000 \\
\hline 68 & 9.357 & .053 & .999 \\
\hline 65 & 9.146 & .058 & .996 \\
\hline
\end{tabular}


Observation number

\begin{tabular}{|l}
\hline \\
\hline
\end{tabular}

\begin{tabular}{l}
6 \\
66 \\
7 \\
8 \\
\hline 57 \\
\hline
\end{tabular}

\begin{tabular}{|l|l|}
\hline 7 & 8.9 \\
\hline 8 & 8.9 \\
\hline 57 & 8.8 \\
\hline
\end{tabular}

Mahalanobis d-squared

9.06

\begin{tabular}{|l|l}
\hline 51 \\
\hline 59 \\
\hline 5
\end{tabular}

\begin{tabular}{|l|l}
\hline 5 & \\
\hline 6 & 8 \\
\hline 15 & \\
\hline 1 & \\
\hline
\end{tabular}

10

\begin{tabular}{|l|}
\hline 2 \\
\hline 64 \\
\hline 4 \\
\hline
\end{tabular}

\begin{tabular}{|l|l|}
\hline 64 & 8.50 \\
\hline 4 & 8 \\
\hline 3 & 8.38 \\
\hline 9 & 8.29 \\
\hline 11 & 8.08 \\
\hline
\end{tabular}

\begin{tabular}{ll}
9 \\
\hline 11 \\
63
\end{tabular}

\begin{tabular}{|l}
11 \\
\hline 35 \\
\hline
\end{tabular}

\begin{tabular}{|l}
63 \\
\hline 35 \\
\hline 60
\end{tabular}

\begin{tabular}{|l}
\hline 6 \\
\hline 50 \\
\hline 137 \\
\hline
\end{tabular}

\begin{tabular}{|l|l|l|l|}
\hline 50 & 7.702 & .101 & .040 \\
\hline 137 & 7.463 & .103 & .031 \\
\hline 49 & 7.287 & .113 & .049 \\
\hline 62 & 7.002 & .121 & .062 \\
\hline 48 & 6.470 & .136 & .118 \\
\hline 23 & 6.347 & .167 & .396 \\
\hline 61 & 6.253 & .175 & .422 \\
\hline 47 & 6.198 & .181 & .426 \\
\hline 81 & 5.933 & .185 & .398 \\
\hline 12 & 5.914 & .204 & .569 \\
\hline 22 & 5.807 & .206 & .510 \\
\hline 109 & 5.751 & .214 & .538 \\
\hline 46 & 5.462 & .219 & .519 \\
\hline 13 & 5.088 & .243 & .727 \\
\hline 45 & 4.928 & .278 & .924 \\
\hline 21 & 4.886 & .295 & .956 \\
\hline & & .299 & .951 \\
\hline
\end{tabular}




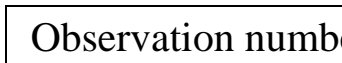

\begin{tabular}{|l}
\hline 110 \\
\hline 136 \\
\hline \\
\hline 56 \\
\hline 43 \\
\hline
\end{tabular}

110

\begin{tabular}{|l|}
\hline 136 \\
\hline 44
\end{tabular}

56

56

43

\begin{tabular}{|l|l|}
\hline 43 & 4.2 \\
\hline 164 & 4.2 \\
\hline 42 & 4.1
\end{tabular}

20

\begin{tabular}{|l|l|}
\hline 20 & 4.09 \\
\hline 111 & 4.04 \\
\hline 100 & 4.03 \\
\hline 108 & 4.00 \\
\hline 130
\end{tabular}

139

\begin{tabular}{|l}
139 \\
\hline 70 \\
\hline 140 \\
\hline
\end{tabular}

\begin{tabular}{|l}
\hline 1 \\
\hline 87 \\
\hline 88 \\
\hline
\end{tabular}

\begin{tabular}{|l}
88 \\
\hline 116 \\
\hline 138 \\
\hline 141
\end{tabular}

\begin{tabular}{|l|}
\hline 138 \\
\hline 41 \\
\hline 71 \\
\hline
\end{tabular}

\begin{tabular}{|l|}
\hline 4 \\
\hline 7 \\
\hline 162 \\
\hline
\end{tabular}

\begin{tabular}{|l|l|l|l|}
\hline 71 & 3.604 & .462 & .988 \\
\hline 37 & 3.418 & .490 & .998 \\
\hline 162 & 3.381 & .496 & .997 \\
\hline 163 & 3.365 & .499 & .997 \\
\hline 36 & 3.344 & .502 & .996 \\
\hline 38 & 3.322 & .505 & .995 \\
\hline 72 & 3.307 & .508 & .993 \\
\hline 40 & 3.286 & .511 & .992 \\
\hline 115 & 3.271 & .514 & .989 \\
\hline 19 & 3.264 & .515 & .985 \\
\hline 86 & 3.231 & .520 & .984 \\
\hline 39 & 3.217 & .522 & .980 \\
\hline 24 & 3.201 & .525 & .975 \\
\hline 161 & 3.178 & .528 & .971 \\
\hline 145 & 3.164 & .531 & .964 \\
\hline 85 & 3.116 & .539 & .968 \\
\hline
\end{tabular}




\begin{tabular}{|l|l|l|l|}
\hline Observation number & Mahalanobis d-squared & $\mathrm{p} 1$ & $\mathrm{p} 2$ \\
\hline 107 & 3.074 & .546 & .970 \\
\hline 158 & 3.048 & .550 & .966 \\
\hline 84 & 3.015 & .555 & .965 \\
\hline 151 & 3.006 & .557 & .955 \\
\hline 160 & 2.974 & .562 & .954 \\
\hline 135 & 2.951 & .566 & .948 \\
\hline 112 & 2.924 & .571 & .943 \\
\hline 159 & 2.916 & .572 & .929 \\
\hline 52 & 2.910 & .573 & .909 \\
\hline 157 & 2.891 & .576 & .896 \\
\hline 152 & 2.870 & .580 & .885 \\
\hline 14 & 2.858 & .582 & .863 \\
\hline 25 & 2.796 & .593 & .888 \\
\hline 114 & 2.772 & .597 & .879 \\
\hline 156 & 2.771 & .597 & .845 \\
\hline 113 & 2.771 & .597 & .804 \\
\hline 106 & 2.755 & .600 & .781 \\
\hline 155 & 2.729 & .604 & .768 \\
\hline 154 & 2.722 & .605 & .728 \\
\hline 153 & 2.707 & .608 & .698 \\
\hline 77 & 2.701 & .609 & .650 \\
\hline 34 & 2.686 & .612 & .617 \\
\hline 148 & 2.685 & .612 & .556 \\
\hline
\end{tabular}

Source: Output of AMOS

\subsection{Result of Path}

Based on Table 3, there are two indirect effects. First, there is the indirect effect between the inflation on economic growth through the stock market which obtained a coefficient of 0.005 , which is not significant. In other words, the stock market is not a mediating variable between inflation and economic growth. Second, there is an indirect influence between the exchange rate on economic growth through the stock market, which obtained a coefficient of 0.046 which is not significant. In other words, the stock market is not a mediating variable between the exchange rate and economic growth. 
Table 3. Analysis of Path Model: Mediation Effect Through Stock Markets

\begin{tabular}{|l|l|l|l|l|}
\hline Indirect Effect & \multicolumn{2}{|l|}{ Direct Effect Coefficient } & $\begin{array}{l}\text { Indirect Effect } \\
\text { Coefficient }\end{array}$ & Information \\
\hline $\begin{array}{l}\text { Inflation } \rightarrow \text { Stock } \\
\text { market } \\
\text { Economic growth }\end{array}$ & $\begin{array}{l}\text { Inflation } \\
\rightarrow \text { Stock market } \\
=0.088 *\end{array}$ & $\begin{array}{l}\text { Stock market } \rightarrow \\
\text { Economic growth } \\
=-0.059 \mathrm{~ns}\end{array}$ & $\begin{array}{l}\text { Not } \\
\text { Signifikan }\end{array}$ \\
\hline $\begin{array}{l}\text { Exchange rate } \rightarrow \\
\text { Stock market } \rightarrow\end{array}$ & $\begin{array}{l}\text { Exchange rate } \\
\text { Economic growth } \\
=0.793 *\end{array}$ & $\begin{array}{l}\text { Stock market } \rightarrow \\
\text { Economic growth } \\
=-0.059 \mathrm{~ns}\end{array}$ & 0.046 & $\begin{array}{l}\text { Not } \\
\text { Signifikan }\end{array}$ \\
\hline
\end{tabular}

Source: Output of AMOS

From the results of the study, it shows that inflation and the exchange rate does not have an indirect effect on economic growth through the stock market. This shows that investment in the Indonesian stock market does not affect the way that inflation and the exchange rate work in terms of influencing economic growth. This is not in accordance with the initial assumption that investment can affect the way that inflation and the exchange rate works. This is possible due to several things. First is the low contribution of the Consumer Goods Industry on sustaining GDP growth. Basirat, Mehdi \& Nasirpour (2014) reinforced this in their research where the financial markets, as the mediation variable, showed that the role and size of the financial markets as an intermediation will determine whether the effect of inflation and the exchange rate on economic growth will be significant or insignificant. During the author's study period, the proportion of stock traded on GDP ranges on average around $11 \%$. The proportion of Consumer Goods Industry stock traded in $2004-2011$ reached an average of $2 \%$ of GDP and this increased to $6 \%-8 \%$ of GDP after 2011 up until 2017 (see Figure 2).

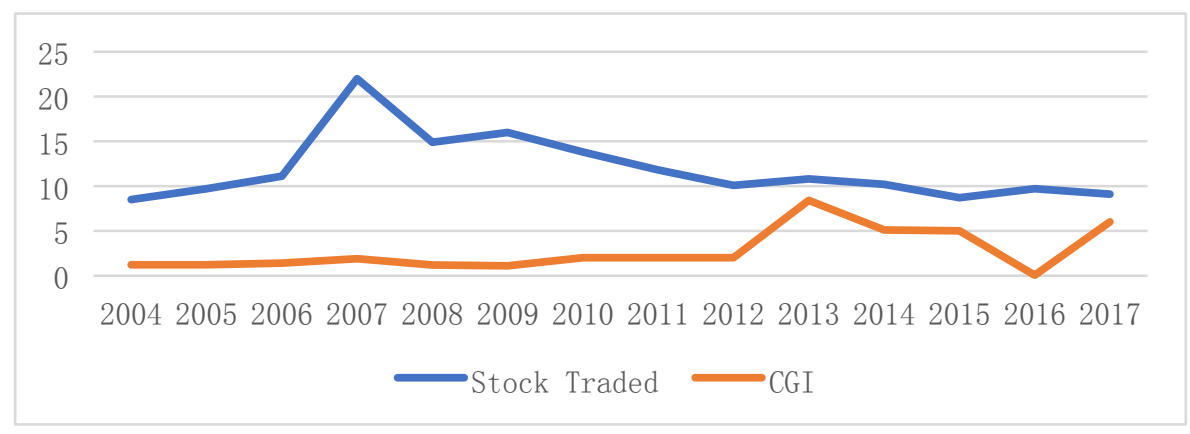

Figure 2. Proportion of Stock Traded on GDP

Source: World Bank, processed

The second factor that is thought to cause investment to not significantly affect the way that inflation and the exchange rate works in reference to influencing economic growth is the liquidity of the stock market. Alajekwu \& Achugbu (2012) and Cooray (2010) revealed that 
the size and liquidity of the stock market determines its role in economic growth. The role of the stock market will be rejected by countries with a small and less liquid stock market (Boubakari \& Jin, 2010). Based on the financial inclusion index, the capital market, which the stock market is a part of, has the lowest rank at only $0.1 \%$ in 2013 and $1.3 \%$ in 2016 (OJK, 2017b). This shows that almost nobody has an awareness of accessing the stock market per one hundred people in 2013 and only one person per one hundred in 2016 had access to the stock market.

The third factor is the lack of integration in the stock market and economic growth. Hong Vo et al (2019) confirmed that the rapidly growing stock market in high-income countries is more integrated with economic growth compared to upper-middle income countries. Indonesia is categorized as an upper-middle income country. In 2017, Indonesia's GDP was ranked 16th in the world with a total GDP of 1,015,421 million of US \$ dollars (World Bank, 2019). If talking about the ease of investment and business in Indonesia, then it is still relatively difficult. Indonesia's Ranking Ease of Doing Business is 91 (BKPM, 2017). This is thought to be the cause of foreign investors preferring to invest in other countries, especially developed countries.

\section{Conclusion}

The impact of inflation and the exchange rate on economic growth in Indonesia through the stock market is not significant. In other words, the stock market is not a mediating variable and it does not affect the way that inflation and the exchange rate work in terms of influencing economic growth. Several factors are thought to be the cause. First is the size of the Indonesian stock market. The stock market in Indonesia is not fully developed and it is not highly active. It was recorded during the author's study period that the proportion of stock traded on GDP ranged around $11 \%$ on average. The proportion of Consumer Goods Industry stock traded in 2004 reached an average $2 \%$ of GDP and this increased to $6 \%-8 \%$ of GDP after 2011 up until 2017. The second factor is the less liquid nature of the Indonesia stock market. Based on the financial inclusion index, the capital market, that the stock market is a part of, has the lowest rank, coming in at only $0.1 \%$ in 2013 and $1.3 \%$ in 2016. Third is the lack of integration in the stock market and economic growth and the ease of opening a business and investment in Indonesia. It is still relatively difficult. Indonesia's Ranking Ease of Doing Business is at 91 in the world.

\section{References}

Alajekwu, U., \& Achugbu, A. (2012). The Role of Stock Market Development on Economic Growth in Nigeria: A Time Series Analysis. African Research Review, 6(1), 51-70. https://doi.org/10.4314/afrrev.v6i1.5

Arestis, P., \& Baltar, C. T. (2018). A Model of Economic Growth for an Open Emerging Country: Empirical Evidence for Brazil. Structural Change and Economic Dynamics. https://doi.org/10.1016/J.STRUECO.2018.10.005

Ball, L. M. (2011). Money, Banking, and Financial Markets (2nd ed.). New York: Worth Publisher. 
Basirat, Mehdi, Arezoo Nasirpour, A. J. (2014). The Effect of Exchange Rate Fluctuations on Economic Growth Considering The Level of Development of Financial. Asian Economic and Financial Review, 4(4), 517-528.

BKPM. (2017). Perkembangan Realisasi Investasi. [Online] Available:

http://www.indonesia.go.id/in/lpnk/badan-koordinasi-penanaman-modal/2472-profile/365-ba dan-koordinasi-penanaman-modal

Boubakari, A., \& Jin, D. (2010). The Role of Stock Market Development in Economic Growth: Evidence from Some Euronext Countries. International Journal of Financial Research, 1(1), 14-20. https://doi.org/10.5430/ijfr.v1n1p14

Clarida, R., \& Waldman, D. (2007). Is Bad News About Inflation Good News for the Exchange Rate? 8th Jacques Polak Annual Research Conference. [Online] Available: http://www.nber.org/papers/w13010

Combes et al. (2019). Financial Flows and Economic Growth in Developing Countries. Economic Modelling. https://doi.org/10.1016/j.econmod.2019.02.010

Cooray, A. (2010). Do Stock Markets Lead to Economic Growth? Journal of Policy Modeling, 32(4), 448-460. https://doi.org/10.1016/J.JPOLMOD.2010.05.001

Eggoh, J. C., \& Khan, M. (2014). On the Nonlinear Relationship Between Inflation and Economic Growth. Research in Economics, 68(2), 133-143.

https://doi.org/10.1016/J.RIE.2014.01.001

Ehigiamusoe, K., \& Lean, H. (2019). Influence of Real Exchange Rate on the Finance-Growth Nexus in the West African Region. Economies, 7(23).

https://doi.org/10.3390/economies7010023

Evans, G. R. (2014). Exchange Rates (1st edition). [Online] Available: http://www.iso.org/iso/home/standards/currency_codes.htm

Fuad, H. (2013). Keuangan dan Konsumsi Topang Kenaikan IHSG. [Online] Available: https://ekbis.sindonews.com/read/740454/32/keuangan-dan-konsumsi-topang-kenaikan-ihsg1366544712

Garín, J., Robert, L., \& Sims, E. (2018). Intermediate Macroeconomics. [Online] Available: https://www3.nd.edu/ esims1/gls_int_macro.pdf

Gelman, M., Jochem, A., Reitz, S., \& Taylor, M. P. (2015). Real Financial Market Exchange Rates and Capital Flows. Journal of International Money and Finance, 54, 50-69. https://doi.org/10.1016/J.JIMONFIN.2015.02.004

Ginting, E., \& Aji, P. (2015). Summary Of Indonesia's Economic Analysis (No. 02). [Online] Available: www.adb.org (November 25, 2018).

Habib, M. M., Mileva, E., \& Stracca, L. (2016). The Real Exchange Rate And Economic Growth: Revisiting The Case Using External Instruments (No. 1921). [Online] Available: https://www.ecb.europa.eu/pub/pdf/scpwps/ecbwp1921.en.pdf 


\section{Al Macrothink}

Business and Economic Research ISSN 2162-4860 2019, Vol. 9, No. 4

Haller, A.-P. (2012). Concepts of Economic Growth and Development. Challenges of Crisis and of Knowledge. Economy Transdisciplinarity Cognition, 15(1), 66-71. [Online] Available: www.ugb.ro/etc

Hong Vo, D., Van Nguyen, P., Minh Nguyen, H et al. (2019). Derivatives Market and Economic Growth Nexus: Policy Implications For Emerging Markets. The North American Journal of Economics and Finance. https://doi.org/10.1016/J.NAJEF.2018.10.014

Kara, A., \& Nelson, E. (2002). The Exchange Rate and Inflation in the UK (No. 11). [Online] Available: https://www.econstor.eu/bitstream/10419/84686/1/extmpcpaper0011.pdf

Labonte, M. (2011). Inflation: Causes, costs, and current status. [Online] Available: https://pdfs.semanticscholar.org/48ac/7bf4dd4a6c9bce7c05722506274307bba096.pdf

Mankiw, N. G. (2016). Macroeconomics , Ninth Edition (9th ed.). New York: Worth Publisher .

OECD. (2018). Active with Indonesia. [Online] Available: http://www.oecd.org/indonesia/Active-with-Indonesia.pdf

Ogrokhina, O., \& Rodriguez, C. M. (2019). The Effect of Inflation Targeting and Financial Openness on Currency Composition of Sovereign International Debt. Journal of International Money and Finance, 97, 1-18. https://doi.org/10.1016/j.jimonfin.2019.05.004

OJK. (2010). Indeks Harga Saham Bursa Efek Indonesia. [Online] Available: https://www.idx.co.id/media/1481/buku-panduan-indeks-2010.pdf

OJK. (2017a). Highlight Sektor Barang Konsumsi. Jakarta: Indonesia.

OJK. (2017b). Strategi Nasional Literasi Keuangan Indonesia. [Online] Available: https://www.ojk.go.id/id/berita-dan-kegiatan/publikasi/Documents/Pages/Strategi-Nasional-L iterasi-Keuangan-Indonesia-(Revisit-2017)-/SNLKI (Revisit 2017)-new.pdf

Parkin, M. (2012). Macroeconomics (10th ed., Vol. 39; D. Battista, Ed.). Pearson.

Patel, N., \& Villar, A. (n.d.). Measuring Inflation (No. 89). [Online] Available:

https://www.bis.org/publ/bppdf/bispap89b_rh.pdf

Pitia, E., \& Lado, Z. (2015). Test of Relationship Between Exchange Rate and Inflation in South Sudan: Granger-Causality Approach. Economics, 4(2), 34-40.

https://doi.org/10.11648/j.eco.20150402.13

Ramachandran, R. D. S. (2014). A Study about Foreign Direct Investment in Indonesia. IOSR Journal of Business and Management, 16(12), 45-47. [Online] Available:

https://pdfs.semanticscholar.org/5fd8/7596e8c7dff434fcfd6871f9d2fc2179f626.pdf

Ribeiro, R. S. M., McCombie, J. S. L., \& Lima, G. T. (2019). Does Real Exchange Rate Undervaluation Really Promote Economic Growth? Structural Change and Economic Dynamics. https://doi.org/10.1016/J.STRUECO.2019.02.005

Shakhaowat Hossin, M. (2016). The Relationship Between Inflation and Economic Growth 


\section{Macrothink}

Business and Economic Research

ISSN 2162-4860

2019, Vol. 9, No. 4

of Bangladesh: An Empirical Analysis from 1961 to 2013. International Journal of Economics, Finance and Management Sciences, 3(5), 426.

https://doi.org/10.11648/j.ijefm.20150305.13

Snowdon, B., \& Vane, H. R. (2005). Modern Macroeconomics. Massachusetts: Edward Elgar Publishing Inc.

Streiner, D. L. (2005). Finding Our Way: An Introduction to Path Analysis. The Canadian Journal of Psychiatry, 50(2), 115-122. https://doi.org/10.1177/070674370505000207

Unctad. (2017). World Investment Report 2017 - Investment And Digital Economy. [Online] Available: https://unctad.org/en/PublicationsLibrary/wir2017_en.pdf

Vinayagathasan, T. (2013). Inflation and Economic Growth: A Dynamic Panel Threshold Analysis for Asian Economies. Journal of Asian Economics, 26, 31-41.

https://doi.org/10.1016/J.ASIECO.2013.04.001

Wilson, J. E. O., Matthews, C., Goodall, J., et al. (n.d.). Economic Grwoth. Retrieved from www.steadystate.orginfo@steadystate.org•+1541-602-3097

World Bank. (2019). World Development Indicators Database. [Online] Available: https://databank.worldbank.org/data/download/GDP.pdf

Yang, B. Z., \& Zeng, T. (2014). A Note on the Real Currency Exchange Rate: Definitions and Implications. Journal of International Business and Economics, 2(4), 2374-2194.

https://doi.org/10.15640/jibe.v2n4a3

\section{Copyright Disclaimer}

Copyright for this article is retained by the author(s), with first publication rights granted to the journal.

This is an open-access article distributed under the terms and conditions of the Creative Commons Attribution license (http://creativecommons.org/licenses/by/3.0/). 